\title{
Leisure Spaces Shared by Grandparents and Grandchildren in Northern Spain
}

\author{
Magdalena Sáenz de Jubera Ocón *, Eva Sanz Arazuri ${ }^{\circledR}$, María Ángeles Valdemoros San Emeterio (), \\ Rosa Ana Alonso Ruiz (D) and Ana Ponce de León Elizondo \\ Department of Ciencias de la Educación, University of La Rioja, 26004 Logroño, Spain; \\ eva.sanz@unirioja.es (E.S.A.); maria-de-los-angeles.valdemoros@unirioja.es (M.Á.V.S.E.); \\ rosa-ana.alonso@unirioja.es (R.A.A.R.); ana.ponce@unirioja.es (A.P.d.L.E.) \\ * Correspondence: m-magdalena.saenz-de-jubera@unirioja.es
}

check for updates

Citation: Sáenz de Jubera Ocón, M.; Sanz Arazuri, E.; Valdemoros San Emeterio, M.Á.; Alonso Ruiz, R.A.; Ponce de León Elizondo, A. Leisure Spaces Shared by Grandparents and Grandchildren in Northern Spain. Sustainability 2021, 13, 9191. https://doi.org/10.3390/su13169191

Academic Editor: Javier Sánchez García

Received: 1 July 2021

Accepted: 11 August 2021

Published: 16 August 2021

Publisher's Note: MDPI stays neutral with regard to jurisdictional claims in published maps and institutional affiliations.

Copyright: (C) 2021 by the authors Licensee MDPI, Basel, Switzerland. This article is an open access article distributed under the terms and conditions of the Creative Commons Attribution (CC BY) license (https:/ / creativecommons.org/licenses/by/ $4.0 /)$.

\begin{abstract}
Spaces are the backbone of intergenerational leisure interests and experiences. The objective of this research was to examine the spaces used in the practice of leisure shared by grandparents and grandchildren and their link with the geographical area of residence. A cross-sectional telematic survey was carried out in which 357 grandparents with grandchildren between 6 and 12 years of age living in the northern part of Spain participated, and a descriptive study and inferential analysis of the data were carried out. The results revealed that a descriptive and inferential analysis was performed. The preferred space for intergenerational leisure was the home, especially for cultural activities such as board games, watching television, and reading. Associations, municipal spaces (sports centers, cultural centers, playrooms), and educational centers are more frequently used in the inland populations. Residing in urban towns and coastal municipalities implies a greater preference for the use of private leisure spaces. Living in provinces with a wetter, rainy climate is related to more shared leisure practice at home. The possible exceptionality of the current situation, within the framework of COVID-19, which may have led to significant alterations in the grandparentgrandchildren relationship, is discussed, with the consequent need to continue this line of inquiry.
\end{abstract}

Keywords: spaces; leisure; grandparents; grandchildren; geographical area

\section{Introduction \\ 1.1. Spaces and Leisure}

Open, closed, public, or private spaces are privileged places for citizens' action and community life in the population. The heterogeneity of spaces, as well as of leisure practices, allows people to act and participate and to share, appropriate, and transform, individually and collectively, the spaces that make up each territory [1]. In the configuration of cities, planning, design, and urban architecture are very important when generating the spatial conditions that lead to the promotion of leisure practices, interactions, flows between different generations, exchanges, and intergenerational experiences aimed at enriching the lives of its inhabitants and shaping a more inclusive society [1,2]. The authors of [3] also state that the configuration of a locality is not only influenced by the architectural elements and equipment, as promoters of leisure practices and events, but also that leisure experiences themselves establish the architectural arrangement of the contemporary city, transforming physical spaces into social, experiential, and relational spaces [4].

Previous studies $[1,5]$ highlight that public space is the main backbone of the expression of interests, sociability, exchange processes, and collective experiences. Despite the social and coexistential relevance granted to public space, other authors [6] consider that, due to aspects related to citizen insecurity, public places in cities have become spaces where leisure practices are performed in a harmful and conflictive way. This generates a decrease in opportunities for encounters, socialization, and the development of empathy. The same author asserts that, in the case of cities, private spaces intended for leisure, such 
as shopping malls or private sports facilities, have become new emerging leisure spaces, especially for older people, who appropriate them as places of significant leisure for social encounters. Aware of the relevance of the potentials of public space, [6] is committed to its recovery for the development of leisure, promoting the improvement of citizen security. In this line, [7] advocate the rescue of culture in the public space, combined with the construction of new habits of coexistence between the different population profiles. This upward trend of commitment to public space in cities to facilitate generational integration must be complemented by people's use of spaces because they are the ones who grant space its true function and build its meaning [8].

\subsection{Intergenerational Relationships and Leisure}

The intergenerational relationship between grandparents and grandchildren implies reciprocal processes of influence, exchange, and learning between the two generations, which is more than coinciding in a given space $[9,10]$. The health status, personal interests, age, gender, social class, as well as the frequency of contact between grandparents and grandchildren or the social plans all influence the essence of these relationships and the shared activities [11]. In particular, leisure, a source of enjoyment and fun, when shared by grandparents and grandchildren, can contribute to strengthening family ties and intergenerational relationships, as well as turning these joint experiences into a source of human development for both generations [12].

Among the leisure practices shared by grandparents and grandchildren before the policies of home isolation and mobility restrictions for the control of COVID-19, those related to playing, outings to the square, or telling stories, conversations, etc., stood out [9,13-15], confirming that grandmothers shared tasks related to cooking, reading, and schoolwork with their grandchildren, and grandfathers collaborated with their grandchildren in the use of technology [9]. On another hand, the leisure activities shared the least by grandparents and grandchildren were listening to music, reading, and going on excursions and trips to the countryside or the beach [13-15]. A booming activity, but still little researched, is the "Grandtravel" phenomenon, an activity referring to family holidays that contribute to individual and intergenerational well-being [16].

\subsection{Intergenerational Spaces Related Factors}

In reference to the use of space, either public or private, studies such as those of [17] point out that this depends on the purchasing power of the territories, given that the concentration of cultural infrastructures occurs in areas with more economic resources, forcing areas with fewer resources to take refuge in the domestic space.

In this line, the research of [18] declares that the promotion of artistic, cultural, recreational, sports, etc., proposals in urban public spaces has a positive impact on participation and the improvement of interpersonal relationships. Public spaces represent ideal places for encounters, coexistence, and social interaction between different generations.

These public spaces refer to squares, streets, parks, or promenades, among others, that cities have modernized to turn them into privileged leisure settings, in which significant and satisfactory intergenerational experiences take place, favoring personal and social well-being and generating benefits in social relations, as well as improving quality of life $[19,20]$. Specifically, the research of [7] points out that the square or the street are spaces of transition and connection between domestic places and the city, which makes it necessary to recognize common urban spaces as socio-ecological assets with transformative power due to their potential to promote the exchange of social, cultural, and natural capital [21].

Studies such as those of [17] indicate that the use of public or private space depends on the purchasing power of the territories, given that the concentration of cultural infrastructures occurs in areas with more economic resources, forcing areas with fewer resources to take refuge in the domestic space.

There is limited research on whether living in metropolitan areas improves the wellbeing of grandparents and grandchildren [22], although some studies $[7,23]$ explain that, 
while relationships between generations are maintained and are more solid in the family environment, they can be adapted to public places through the creation of optimal conditions, including specific furniture that generates practices and fosters intergenerational relationships.

There are few studies concerning intergenerational relationships of grandparents and grandchildren that compare the place of residence depending on whether it is rural or urban. Some of these studies showed that rural grandparents are better considered and valued by their relatives; they were also more respected and felt more included in the life of their villages, which led to greater social recognition and a sense of well-being [24]. An investigation in China showed that urban grandparents had better health due to the provision of care to their relatives, and they considered their care of the grandchildren as a reciprocal form of intergenerational exchange rather than an altruistic and emotionally rewarding activity. It was also found that rural grandmothers' health was the most vulnerable because of the intergenerational care they provided [25].

Considering the spaces shared by grandparents and grandchildren, the scientific literature highlights the home, which hosts activities related to informal learning, literacy, and language development through intergenerational exchanges [24]. Museums have also been the subject of study in some research [26-28], considered spaces for intergenerational encounters and learning that allow sharing an enriching experience. Other studies [29-31] have focused on flexible, outdoor spaces, where grandparents and grandchildren share attractive and enriching intergenerational experiences, such as family or urban gardens that are emerging as one of the priority activities shared by grandchildren and grandparents in nature, which entail intergenerational learning, sensitivity, and environmental sustainability [32-36]. In addition, in natural spaces and outdoors, other activities shared by grandparents and grandchildren are noteworthy, such as walks, experiences in contact with nature, or the care of animals and plants [37], essential for intergenerational well-being [38].

The objective of this study was to examine the spaces used in the practice of leisure shared by grandparents and grandchildren, and their link with the geographical area of residence, to make feasible proposals adapted to the territorial reality.

The present study proposes that municipal spaces (sports centers, cultural centers, playrooms, etc.), educational centers and associations, clubs and social cliques are more frequently used for the practice of intergenerational leisure by grandparents and grandchildren who live inland than by those who reside on the coast (Hypothesis 1). In addition, it states that living in rural and urban municipalities is a conditioning factor in the use of spaces for grandparents' and grandchildren's shared leisure (Hypothesis 2). Furthermore, it holds that when grandparents and grandchildren reside in provinces with rainier climates, their homes are the preferred place for shared leisure (Hypothesis 3).

\section{Materials and Methods}

\subsection{Study Design}

A cross-sectional telematic survey was carried out in which participants were grandparents living in Spain with grandchildren between 6 and 12 years of age, living in the northern part of Spain.

The researchers contacted the participants by telephone.

\subsection{Participants}

This work is part of a larger study in which the universe was made up of the total number of 6- to 12-year-old children, living in the north of Spain, plus their living grandparents. Taking into consideration that in the Spanish state, that every child from 6 to 12 years of age has to be enrolled in an educational center and that the population of grandparents with grandchildren between 6 and 12 years old was difficult to identify, the study population was defined from the statistical data published by the ministries and education departments of each of the autonomous communities that make up the northern 
area of Spain. The data collected show a population size of 250,357 of Primary Education students in northern Spain.

Setting an absolute error of 3\%, a 95\% confidence level, and considering the assumption of $\mathrm{p}=\mathrm{q}=0.5$, the sample size is estimated at 1075 students. With an experimental mortality of $1.11 \%$, the final sample size consisted of 1063 students.

The final sample units of students were selected by means of proportional sampling, stratified by province and clusters, selecting all the students from the classrooms chosen from among the randomly selected centers. In order to be part of the sample, it was an essential requirement for each student to have the informed and signed consent of their parent or legal guardian. In the authorization form, the parents or legal guardians were asked to provide the phone number of a grandparent of the child. We obtained 357 phone numbers of grandparents.

Thus, 357 grandparents with grandchildren aged 6 to 12 participated in this study. They lived in the northern part of Spain, made up of 8 Spanish provinces: Cantabria, Biscay, Gipuzkoa, Alava, La Rioja, Navarre, Burgos, and Palencia (Figure 1). These 8 provinces contain a population of 250,357 primary school students between the ages of 6 and 12, according to statistical data published by the ministries and departments of education of each autonomous community. Of the participants, $25.3 \%$ were male and $74.7 \%$ were female. Concerning age, $25.2 \%$ of the grandparents were under the age of $65,51.8 \%$ were between the ages of 65 and 74 , and $21.6 \%$ were 75 years of age or older.

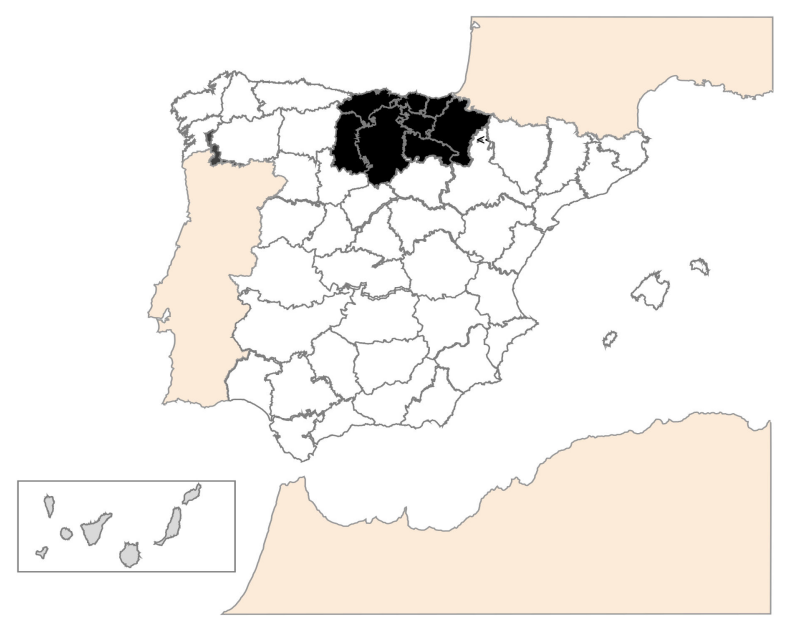

Figure 1. Northern area of Spain (according to the Nielsen areas): Cantabria, Biscay, Gipuzkoa, Alava, La Rioja, Navarre, Burgos, and Palencia (shaded in black).

The northern part of Spain has a heterogeneous climate and differences in the temperature between the provinces despite being adjacent. Alava, La Rioja, Burgos, and Palencia are characterized by very cold and humid winters and very hot and dry summers, whereas in Navarre, there is a great variety of climatic nuances, ranging from areas with a temperate climate with abundant rainfall to dry areas with desert features and surfaces with high thermal conditions and abundant precipitation in the form of snow. In the provinces of Cantabria, Biscay, Gipuzkoa, and Navarre, extreme temperatures are not reached either in winter or in summer, but their rainfall is abundant throughout the year. This Spanish region is of great international interest because its climate reproduces the climate of other European and Asian countries.

The selection of participants was carried out through the application for permission and telephone number to the parents of a sample of 1075 students of primary education through stratified and proportional probabilistic selection by province (Table 1). 
Table 1. Target sample of the study. Grandparents of children in Primary Education (6-12 years) in northern Spain.

\begin{tabular}{cccc}
\hline & Provinces & Frequency & Percentage Valid \\
\hline & Cantabria & 35 & $9.9 \%$ \\
& Biscay & 65 & $18.3 \%$ \\
& Gipuzkoa & 19 & $4.9 \%$ \\
& Alava & 46 & $13.0 \%$ \\
NORTHERN SPAIN & La Rioja & 90 & $25.3 \%$ \\
& Navarre & 45 & $12.6 \%$ \\
& Burgos & 15 & $4.2 \%$ \\
& Palencia & 22 & $6.2 \%$ \\
& Another province & 20 & $5.6 \%$ \\
& TOTAL & 357 & $100 \%$ \\
\hline
\end{tabular}

\subsection{Instruments}

The absence of a valid and reliable instrument to collect the relevant information of this study led to the development of an ad-hoc questionnaire to gather the data through 5 variables: space used to share leisure activities by grandparents and grandchildren, leisure activity shared by grandparents and grandchildren, geographical location of the place of residence of the grandparents, type of municipality in which the grandparents reside, province of residence of the grandparents.

The variables recorded for this study are defined below:

- $\quad$ Space used to share leisure activities by grandparents and grandchildren: this is a categorical variable that records the place where the participants share some kind of leisure activity with their grandchildren. The established categories are: at home (of grandparents or grandchildren); in associations, clubs, societies or social cliques; in municipal spaces (sports centers, cultural centers, playrooms, etc.); in open public spaces (street, park, square, etc.); at home (of the grandparents or the grandchildren); in private leisure spaces (bars, shopping malls ... ); in nature; in the school facilities.

- Leisure activity shared by grandparents and grandchildren: This is a categorical variable that records whether participants share each kind of leisure activity with their grandchildren (cultural activities, screen activities, festive activities, creative activities, recreational activities, solidary activities, ecological-environmental activities, etc.).

- Geographical location of the grandparents' place of residence: this is a dichotomous variable that records whether the grandparent resides on the coast or inland. The variable coast includes those municipalities that border the sea.

- Type of municipality in which the grandparent resides: this is a dichotomous variable that records whether the grandparent resides in a rural or urban municipality. The Spanish National Institute of Statistics identifies as an urban area the set of unique population entities that have more than 10,000 inhabitants; intermediate zone, those with 2001 to 10,000 inhabitants; and rural if it has 2000 or fewer inhabitants.

- Province in which the grandparent resides: this is a categorical variable that records the province in which the grandparent resides. The referred categories are: Cantabria, Biscay, Gipuzkoa, Alava, La Rioja, Navarre, Burgos, Palencia, or Another province outside the northern part of Spain.

\subsection{Procedure}

The questionnaire was applied to the grandparents of students from the different randomly selected schools in each of the 8 provinces that make up the northern part of the Spanish state. The consent of the parents or legal guardians of the minors was requested, and they were invited to provide the private telephone number of a grandfather or grandmother of their children. Subsequently, grandparents completed the instrument by phone. Seven previously trained researchers personally called each participant by phone. Before starting each interview individually, the confidentiality of the answers was informed 
and guaranteed, as well as the protection of the participants' rights and guarantees. The answers were recorded by the researchers on the digitized questionnaire at the same time as they conducted each interview. The Ethics Committee of the university to which the researchers belong approved this procedure on 17 December 2019. The positive report of this Ethics Committee was recorded with the code CE_02_2019.

\subsection{Analysis}

Using the SPSS 23.0 statistical program, data analysis was performed in two phases: First, a descriptive study was carried out - through the frequency statistic - that allowed for identifying the spaces that most promote the relationships between grandparents and grandchildren in the north of Spain. Secondly, through a segmented descriptive analysis, we identified the leisure activities most shared by grandparents and grandchildren in the spaces most frequented jointly by the two generations.

In the second phase, an inferential analysis was carried out through two tests: (a) Student's parametric T-test for independent samples, to determine possible significant differences in the type of spaces most frequently used by grandparents and grandchildren for shared leisure experiences, depending on whether the grandparents resided on the coast or inland, or in rural or urban municipalities; and (b) A one-factor analysis of variance (ANOVA) that verified the existence of significant differences in the type of spaces most frequently used by grandparents and grandchildren for shared leisure according to the grandparents' province of residence. Variance homogeneity was tested to confirm the assumptions of normality and homoscedasticity. Contrasts were also made using multiple post-hoc comparisons; in those cases where Levene's statistic had equal variances, Tukey's test was used, and when the variance presented different values, the Games-Howell test.

The level of significance established for this study was set at $p<0.05$.

\section{Results}

\subsection{In Which Space in the North of Spain Are the Relations between Grandparents and} Grandchildren Enhanced the Most?

Of the participants, $97.2 \%$ stated that they practice leisure activity with their grandchildren in their own home or in that of the grandchildren. Public spaces (street, park, etc.) constitute the second scenario of leisure relations between grandparents and grandchildren. Private leisure spaces (cinemas, theaters, shopping centers, etc.) and the natural environment are also important spaces of family leisure shared by the two generations (Figure 2).

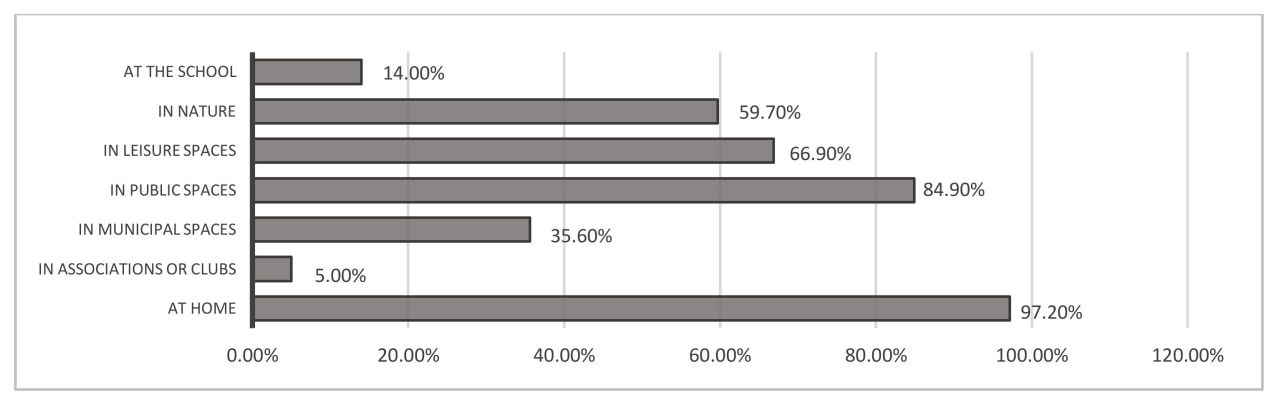

Figure 2. Leisure spaces shared by grandparents and grandchildren.

\subsection{What Are the Leisure Activities Most Frequently Shared at Home by Grandparents and Grandchildren in the North of Spain?}

The leisure activities most frequently shared by grandparents and grandchildren at home are board games (reported by $80.7 \%$ of grandparents), while watching television $(75.4 \%)$ and reading (56\%) complete the list of the three most frequently shared activities at home by the two generations (Figure 3). Artistic activities (47.1\%) and listening to music 
(45.7\%) are also widely shared at home. Up to 22 different types of leisure activities are enjoyed in the home of the grandparents and/or the grandchildren.

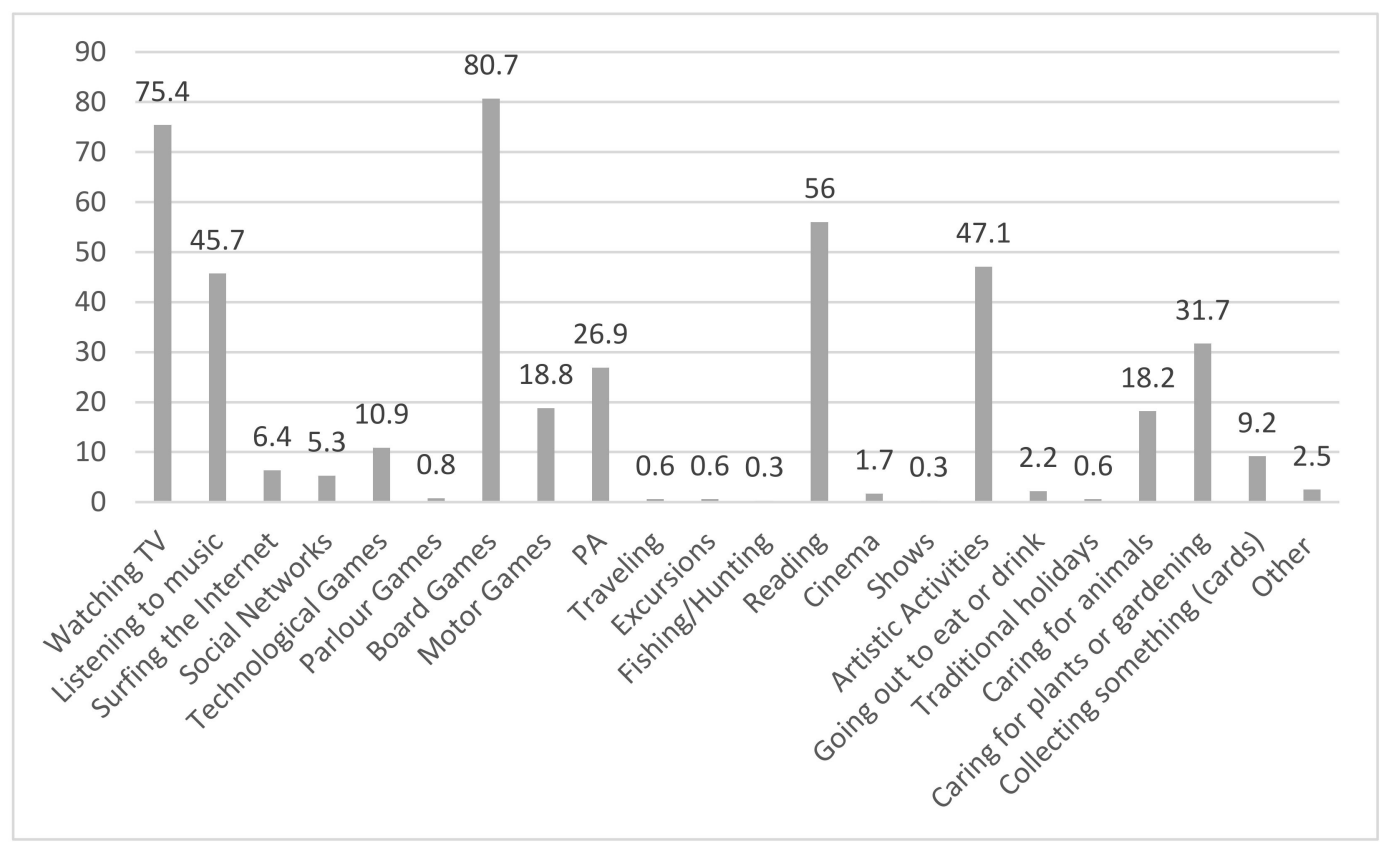

Figure 3. Percentage of grandparents and grandchildren who practice each type of leisure activity at home.

3.3. What Are the Most Frequently Leisure Activities Shared by Grandparents and Grandchildren in Public Spaces in the North of Spain?

In public spaces (park, square, street, etc.), intergenerational family relationships revolve around 12 leisure activities, focusing mainly on going out to eat or drink $(46.8 \%)$, shopping $(36.4 \%)$, practicing a physical activity $(26.9 \%)$, and going to the cinema $(23.5 \%)$ (Figure 4).

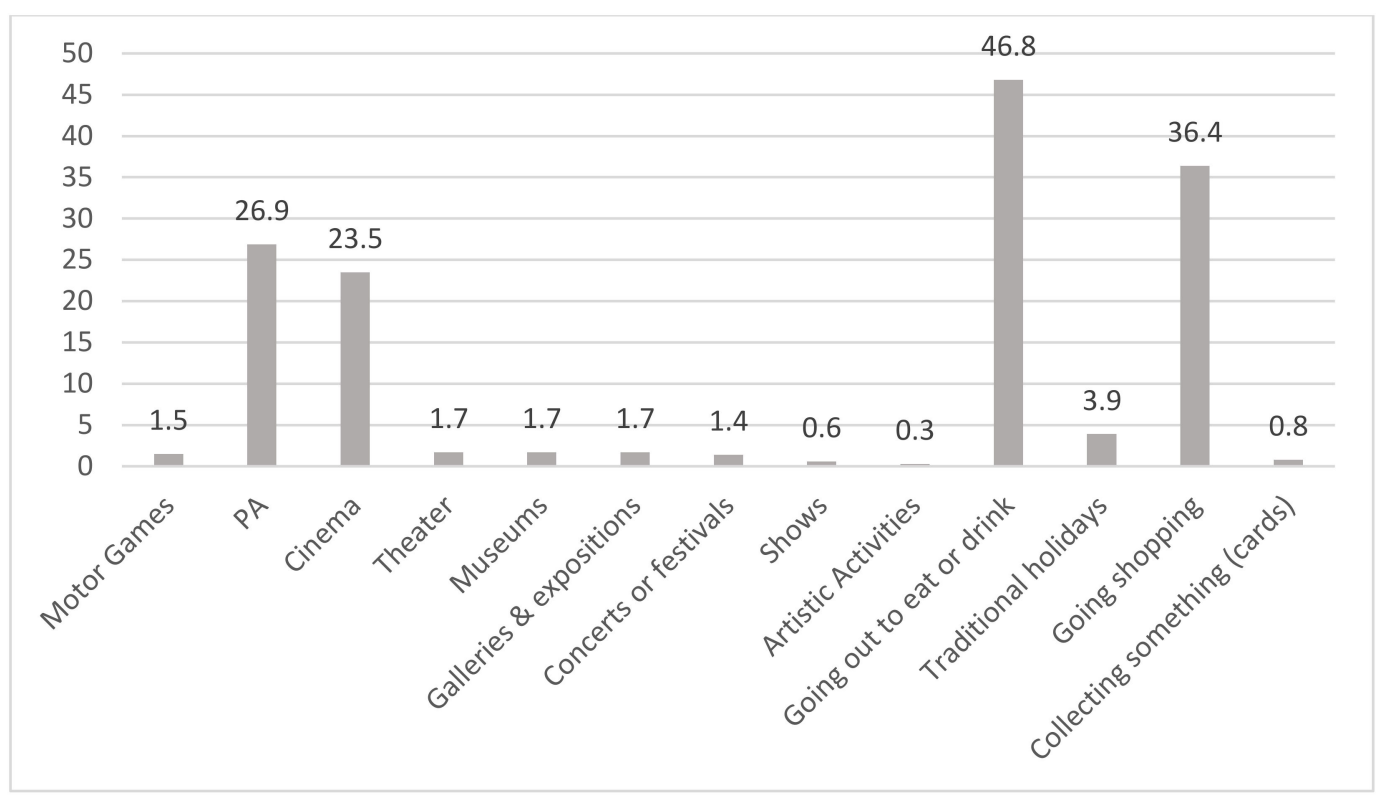

Figure 4. Percentage of grandparents and grandchildren who practice each type of leisure activity in public spaces (park, square, street, etc.). 


\subsection{What Are the Most Frequently Leisure Activities Shared by Grandparents and Grandchildren} in Nature in the North of Spain?

In nature, grandparents share up to 11 types of leisure activities with their grandchildren. Traveling (38.4\%) and hiking (30.8\%) are the main activities of this space. The practice of physical activity (12.3\%), motor games $(4.5 \%)$, fishing and /or hunting $(3.6 \%)$, and caring for plants $(3.1 \%)$ and animals $(2.2 \%)$ are also activities shared by grandparents and grandchildren in the natural environment (Figure 5).

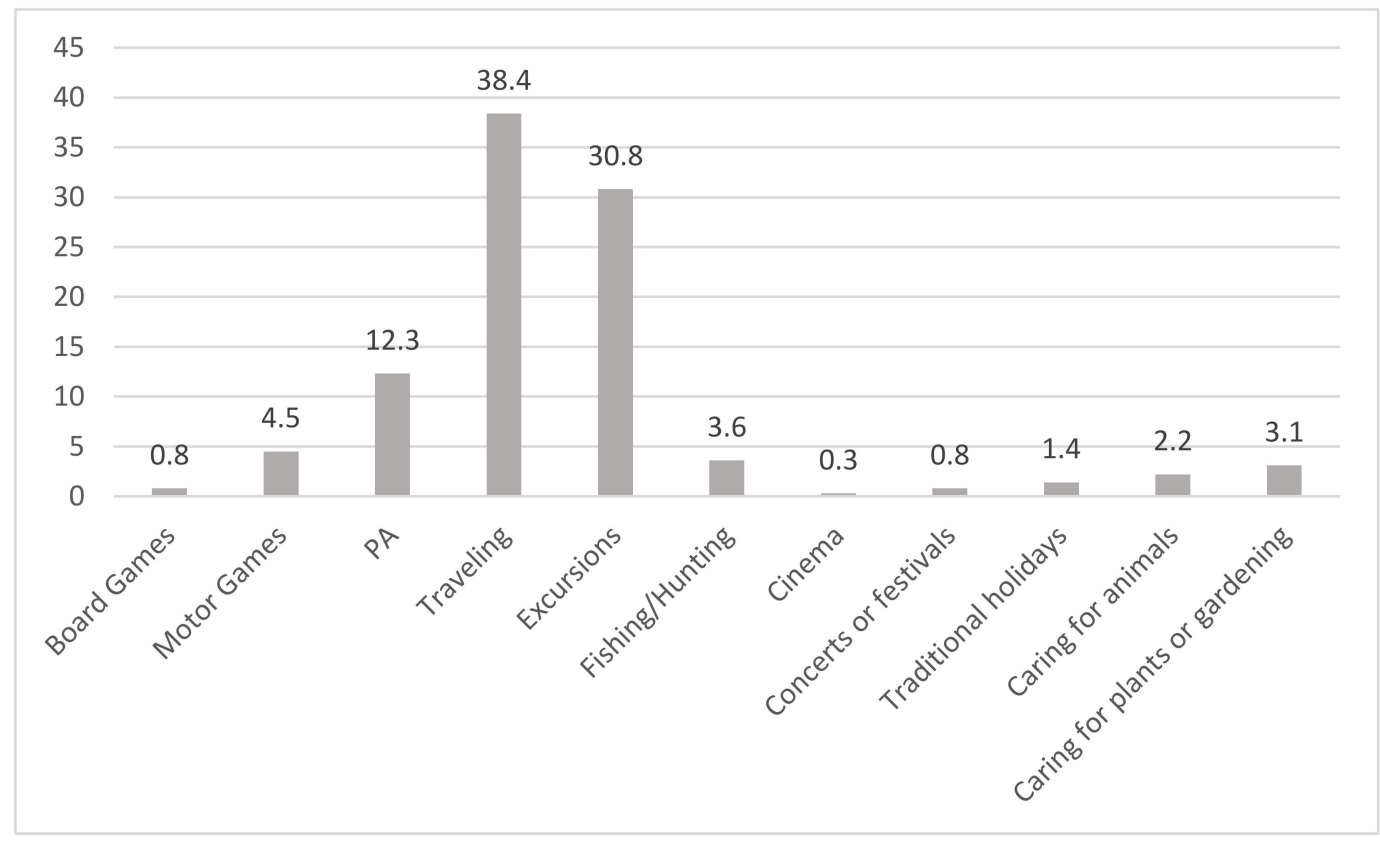

Figure 5. Percentage of grandparents and grandchildren who practice each type of leisure activity in nature.

3.5. Is Residing in a Coastal or Inland Area Linked to the Type of Spaces Used for Grandparents' and Grandchildren's Shared Leisure?

When comparing grandparents living on the coast with those living inland, Student's T-test for independent samples revealed no significant differences in the use of the family home $\left(\bar{X}_{\text {coast }}=4.68 \pm 1.88 ; \bar{X}\right.$ inland $\left.=4.30 \pm 2.43, p>0.10\right)$; public spaces $\left(\bar{X}_{\text {coast }}=2.15 \pm 1.62 ; \bar{X}\right.$ inland $\left.=2.11 \pm 1.75, p>0.10\right)$, and the natural environment $\left(\bar{X}_{\text {coast }}=1.19 \pm 1.26 ; \bar{X}_{\text {inland }}=0.94 \pm 1.17, p>0.10\right)$ for leisure practice by grandparents and grandchildren.

There were significant differences in the use of associations $\left(\bar{X}_{\text {coast }}=0.01 \pm 0.10\right.$; $\bar{X}$ inland $=0.07 \pm 0.28, p<0.005)$, municipal spaces $\left(\bar{X}_{\text {coast }}=0.42 \pm 0.87 ;\right.$ $\bar{X}$ inland $=0.69 \pm 1.21, p<0.05)$, leisure spaces $(\bar{X}$ coast $=1.64 \pm 1.15$; $\bar{X}$ inland $=1.03 \pm 1.07$, $p<0.001)$, and the school ( $\bar{X}_{\text {coast }}=0.08 \pm 0.35$; $\bar{X}$ inland $\left.=0.29 \pm 0.87, p<0.005\right)$ for the practice of leisure by grandparents and grandchildren. Whereas associations, municipal spaces, and schools are more frequently chosen scenarios in inland municipalities for the intergenerational relations of grandparents and grandchildren, private leisure spaces are more frequently chosen in coastal towns to share leisure by the two generations.

3.6. Is Residing in a Rural or Urban Municipality Linked to the Type of Spaces Used for Grandparents' and Grandchildren's Shared Leisure?

The only significant difference depending on whether the municipality is rural or urban was the use of private leisure spaces. In rural areas, these leisure scenarios are significantly less important than in urban localities for the practice leisure shared by grandparents and grandchildren $\left(\bar{X}_{\text {rural }}=0.94 \pm 1.07 ; \bar{X}_{\text {urban }}=1.33 \pm 1.14 ; p<0.05\right)$. 
3.7. Do the Spaces That Most Enhance the Relationships between Grandparents and Grandchildren in the North of Spain Vary Depending on Whether the Grandparents Live in a Certain Province?

The results of the one-factor ANOVA to analyze the possible differences depending on the province in which the grandparents live rejected the equality of the population variances analyzed in the use of all spaces except for the natural environment. Significant differences were found in the practice of leisure shared by grandparents and grandchildren at home, in open public spaces, in private leisure spaces, and in the school. However, no significant differences were found by province in the use of associations, clubs or cliques, municipal spaces, or nature (Table 2).

Table 2. Summary of the one-factor ANOVA: leisure space shared by grandparents and grandchildren considering the grandparents' province of residence.

\begin{tabular}{|c|c|c|c|c|c|c|c|c|}
\hline $\begin{array}{c}\text { Leisure Space } \\
\text { Shared by } \\
\text { Grandparents } \\
\text { and } \\
\text { Grandchildren }\end{array}$ & $\begin{array}{l}\text { Levene's } \\
\text { Statistic }\end{array}$ & $p$ & & $\begin{array}{l}\text { Sum of } \\
\text { Squares }\end{array}$ & $d f$ & $\begin{array}{l}\text { Quadratic } \\
\text { Mean }\end{array}$ & $F$ & $p$ \\
\hline \multirow{3}{*}{ Home } & 3.980 & $0.000^{* * *}$ & Intergroup & 58.881 & 8 & 7.360 & 3.792 & $0.000 * * *$ \\
\hline & & & Intragroup & 671.637 & 346 & 1.941 & & \\
\hline & & & Total & 730.518 & 354 & & & \\
\hline \multirow{3}{*}{$\begin{array}{l}\text { Associations } \\
\text { clubs, or cliques }\end{array}$} & 4.674 & $0.000^{* * *}$ & Intergroup & 0.5621 & 8 & 0.070 & 1.088 & 0.371 \\
\hline & & & Intragroup & 22.312 & 346 & 0.064 & & \\
\hline & & & Total & 22.873 & 354 & & & \\
\hline \multirow{3}{*}{ Municipal spaces } & 3.999 & $0.000^{* * *}$ & Intergroup & 16.794 & 8 & 2.099 & 1.848 & 0.067 \\
\hline & & & Intragroup & 393.104 & 346 & 1.136 & & \\
\hline & & & Total & 409.899 & 354 & & & \\
\hline \multirow{3}{*}{$\begin{array}{l}\text { Open public } \\
\text { spaces }\end{array}$} & 2.782 & $0.005^{* *}$ & Intergroup & 44.508 & 8 & 5.564 & 2.636 & $0.008^{* *}$ \\
\hline & & & Intragroup & 730.354 & 346 & 2.111 & & \\
\hline & & & Total & 774.862 & 354 & & & \\
\hline \multirow{3}{*}{ Leisure spaces } & 3.467 & $0.001^{* * *}$ & Intergroup & 34.823 & 8 & 4.353 & 3.621 & $0.000 * * *$ \\
\hline & & & Intragroup & 415.977 & 346 & 1.202 & & \\
\hline & & & Total & 450.800 & 354 & & & \\
\hline \multirow{3}{*}{ In nature } & 1.888 & 0.061 & Intergroup & 19.864 & 8 & 2.483 & 2.026 & 0.053 \\
\hline & & & Intragroup & 424.034 & 346 & 1.226 & & \\
\hline & & & Total & 443.899 & 354 & & & \\
\hline \multirow{3}{*}{ In the school } & 8.718 & $0.000^{* * *}$ & Intergroup & 10.918 & 8 & 1.365 & 2.598 & $0.009 * *$ \\
\hline & & & Intragroup & 181.730 & 346 & 0.525 & & \\
\hline & & & Total & 192.648 & 354 & & & \\
\hline
\end{tabular}

Note: $p<0.05,{ }^{* *}=p<0.01, * * *=p<0.005$.

By delving into the significant differences in the practice of leisure shared by grandparents and grandchildren at home, and from multiple comparisons using the Games-Howell test, we detected that grandparents living in Cantabria $(\bar{X}=4.48)$ and Gipuzcoa $(\bar{X}=4.52)$ relate more to their grandchildren at home than do grandparents from La Rioja $(\bar{X}=3.58)$ and Palencia $(\bar{X}=3.13)$. Cantabria also showed significant differences compared with Alava $(\bar{X}=3.60)$. No significant differences were identified in the rest of the provinces $\left(\overline{\mathrm{X}}_{\text {Burgos }}=2.86 ; \overline{\mathrm{X}}_{\text {others }}=3.55 ; \overline{\mathrm{X}}_{\text {Navarre }}=3.77 ; \overline{\mathrm{X}}_{\text {Vizcaya }}=4.04\right)($ Table 3$)$. 
Table 3. Multiple comparisons using the Games-Howell test: analysis of the use of the home for the practicecof leisure shared by grandparents and grandchildren considering grandparents' province of residence.

\begin{tabular}{|c|c|c|c|c|}
\hline $\begin{array}{l}\text { (I) Grandparents' } \\
\text { Province of } \\
\text { Residence }\end{array}$ & $\begin{array}{l}\text { (I) Grandparents' } \\
\text { Province of } \\
\text { Residence }\end{array}$ & $\begin{array}{l}\text { Difference of } \\
\text { Means (I-J) }\end{array}$ & Standard Error & $p$ \\
\hline \multirow{8}{*}{ Alava } & Burgos & 0.74203 & 0.50411 & 0.856 \\
\hline & Gipuzkoa & -0.92072 & 0.30142 & 0.080 \\
\hline & La Rioja & 0.01981 & 0.27030 & 1.000 \\
\hline & Navarre & -0.16908 & 0.29525 & 1.000 \\
\hline & Palencia & 0.47233 & 0.34120 & 0.898 \\
\hline & Cantabria & $-0.87702 *$ & 0.26143 & $0.032 *$ \\
\hline & Biscay & -0.43746 & 0.26930 & 0.789 \\
\hline & Other & 0.05870 & 0.42421 & 1.000 \\
\hline \multirow{7}{*}{ Burgos } & Gipuzkoa & -1.66275 & 0.50323 & 0.069 \\
\hline & La Rioja & -0.72222 & 0.48523 & 0.847 \\
\hline & Navarre & -0.91111 & 0.49956 & 0.668 \\
\hline & Palencia & -0.26970 & 0.52801 & 1.000 \\
\hline & Cantabria & -1.61905 & 0.48034 & 0.067 \\
\hline & Biscay & -1.17949 & 0.48467 & 0.325 \\
\hline & Other & -0.68333 & 0.58509 & 0.957 \\
\hline \multirow{6}{*}{ Gipúzcoa } & La Rioja & 0.94052 * & 0.26865 & $0.029 *$ \\
\hline & Navarre & 0.75163 & 0.29374 & 0.233 \\
\hline & Palencia & $1.39305^{* *}$ & 0.33989 & $0.006^{* *}$ \\
\hline & Cantabria & 0.04370 & 0.25972 & 1.000 \\
\hline & Biscay & 0.48326 & 0.26764 & 0.678 \\
\hline & Other & 0.97941 & 0.42316 & 0.365 \\
\hline \multirow{5}{*}{ La Rioja } & Navarre & -0.1889 & 0.26171 & 0.998 \\
\hline & Palencia & 0.45253 & 0.31262 & 0.872 \\
\hline & Cantabria & $-0.89683^{* * *}$ & 0.22285 & $0.003^{* * *}$ \\
\hline & Biscay & -0.45726 & 0.23203 & 0.566 \\
\hline & Other & 0.03889 & 0.40158 & 1.000 \\
\hline \multirow{4}{*}{ Navarre } & Palencia & 0.64141 & 0.33443 & 0.695 \\
\hline & Cantabria & -0.70794 & 0.25254 & 0.132 \\
\hline & Biscay & -0.26838 & 0.26067 & 0.982 \\
\hline & Other & -0.22778 & 0.41878 & 1.000 \\
\hline \multirow{3}{*}{ Palencia } & Cantabria & $-1.34935^{* * *}$ & 0.30499 & $0.003^{* * *}$ \\
\hline & Biscay & -0.90979 & 0.31176 & 0.116 \\
\hline & Other & -0.41364 & 0.45235 & 0.991 \\
\hline \multirow{2}{*}{ Cantabria } & Biscay & 0.43956 & 0.22164 & 0.559 \\
\hline & Other & 0.93571 & 0.39567 & 0.344 \\
\hline Biscay & Other & 0.49615 & 0.40091 & 0.940 \\
\hline
\end{tabular}

Regarding open public spaces, the Games - Howell test showed that Cantabrian grandparents $(\bar{X}=2.68)$ use these scenarios more to relate to their grandchildren than grandparents from Burgos $(\bar{X}=1.13)$. No significant differences were identified in the rest of the provinces $\overline{\mathrm{X}}_{\text {Other }}=1.45 ; \overline{\mathrm{X}}_{\text {Palencia }}=1.59 ; \overline{\mathrm{X}}_{\text {Alava }}=1.78 ; \overline{\mathrm{X}}_{\text {Gipuzkoa }}=1.82 ; \overline{\mathrm{X}}_{\text {Biscay }}=2.09$; $\left.\bar{X}_{\text {Navarre }}=2.15 ; \bar{X}_{\text {La Rioja }}=2.17\right)($ Table 4). 
Table 4. Multiple comparisons using the Games-Howell test: analysis of the use of open public spaces for the practice of leisure shared by grandparents and grandchildren considering grandparents' province of residence.

\begin{tabular}{|c|c|c|c|c|}
\hline $\begin{array}{l}\text { (I) Grandparents' } \\
\text { Province of } \\
\text { Residence }\end{array}$ & $\begin{array}{l}\text { (J) Grandparents' } \\
\text { Province of } \\
\text { Residence }\end{array}$ & $\begin{array}{l}\text { Difference of } \\
\text { Means (I-J) }\end{array}$ & Standard Error & $p$ \\
\hline \multirow{8}{*}{ Alava } & Burgos & 0.64928 & 0.36024 & 0.680 \\
\hline & Gipuzkoa & -0.04092 & 0.35769 & 1.000 \\
\hline & La Rioja & -0.39517 & 0.26775 & 0.864 \\
\hline & Navarre & -0.37295 & 0.32228 & 0.963 \\
\hline & Palencia & 0.19170 & 0.32320 & 1.000 \\
\hline & Cantabria & -0.90311 & 0.35678 & 0.236 \\
\hline & Biscay & -0.30970 & 0.27298 & 0.967 \\
\hline & Other & 0.33261 & 0.32515 & 0.982 \\
\hline \multirow{7}{*}{ Burgos } & Gipuzkoa & -0.69020 & 0.40873 & 0.748 \\
\hline & La Rioja & -1.04444 & 0.33288 & 0.087 \\
\hline & Navarre & -1.02222 & 0.37813 & 0.184 \\
\hline & Palencia & -0.45758 & 0.37891 & 0.949 \\
\hline & Cantabria & $-1.55238 *$ & 0.40794 & 0.013 * \\
\hline & Biscay & -0.95897 & 0.33710 & 0.152 \\
\hline & Other & -0.31667 & 0.38058 & 0.995 \\
\hline \multirow{6}{*}{ Gipuzkoa } & La Rioja & -0.35425 & 0.33011 & 0.973 \\
\hline & Navarre & -0.33203 & 0.37570 & 0.993 \\
\hline & Palencia & 0.23262 & 0.37649 & 0.999 \\
\hline & Cantabria & -0.86218 & 0.40569 & 0.470 \\
\hline & Biscay & -0.26878 & 0.33437 & 0.996 \\
\hline & Other & 0.37353 & 0.37816 & 0.984 \\
\hline \multirow{5}{*}{ La Rioja } & Navarre & 0.02222 & 0.29138 & 1.000 \\
\hline & Palencia & 0.58687 & 0.29239 & 0.547 \\
\hline & Cantabria & -0.50794 & 0.32914 & 0.830 \\
\hline & Biscay & 0.08547 & 0.23570 & 1.000 \\
\hline & Other & 0.72778 & 0.29454 & 0.278 \\
\hline \multirow{4}{*}{ Navarre } & Palencia & 0.56465 & 0.34303 & 0.775 \\
\hline & Cantabria & -0.53016 & 0.37485 & 0.889 \\
\hline & Biscay & 0.06325 & 0.29620 & 1.000 \\
\hline & Other & 0.70556 & 0.34487 & 0.520 \\
\hline \multirow{3}{*}{ Palencia } & Cantabria & -1.09481 & 0.37563 & 0.108 \\
\hline & Biscay & -0.50140 & 0.29719 & 0.751 \\
\hline & Other & 0.14091 & 0.34572 & 1.000 \\
\hline \multirow{2}{*}{ Cantabria } & Biscay & 0.59341 & 0.33341 & 0.695 \\
\hline & Other & 1.23571 * & 0.37731 & 0.045 * \\
\hline Biscay & Other & 0.64231 & 0.29931 & 0.459 \\
\hline
\end{tabular}

Note: $p<0.05,{ }^{*}=p<0.05$.

Compared to Palencia $(\bar{X}=0.54)$, La Rioja $(\bar{X}=0.98)$, and Navarre $(\bar{X}=1.000)$, Biscay $(\bar{X}=1.64)$ presents a greater use of leisure spaces for grandparents' and grandchildren's interrelations through leisure experiences. No significant differences were identified between the rest of the provinces $\left(\overline{\mathrm{X}}_{\text {Alava }}=1.10 ; \overline{\mathrm{X}}_{\text {Cantabria }}=1.20 ; \overline{\mathrm{X}}_{\text {Burgos }}=1.46 ; \overline{\mathrm{X}}_{\text {Other }}=1.50\right.$; $\left.\bar{X}_{\text {Gipuzkoa }}=1.64\right)($ Table 5). 
Table 5. Multiple comparisons using the Games-Howell test: analysis of the use of leisure spaces for the practice of leisure shared by grandparents and grandchildren considering grandparents' province of residence.

\begin{tabular}{|c|c|c|c|c|}
\hline $\begin{array}{l}\text { (I) Grandparents' } \\
\text { Province of } \\
\text { Residence }\end{array}$ & $\begin{array}{l}\text { (J) Grandparents' } \\
\text { Province of } \\
\text { Residence }\end{array}$ & $\begin{array}{l}\text { Difference of } \\
\text { Means (I-J) }\end{array}$ & Standard Error & $p$ \\
\hline \multirow{8}{*}{ Alava } & Burgos & -0.35797 & 0.27462 & 0.921 \\
\hline & Gipuzkoa & -0.53836 & 0.34936 & 0.825 \\
\hline & La Rioja & 0.11981 & 0.18480 & 0.999 \\
\hline & Navarre & 0.10870 & 0.19161 & 1.000 \\
\hline & Palencia & 0.56324 & 0.22061 & 0.233 \\
\hline & Cantabria & -0.09130 & 0.27632 & 1.000 \\
\hline & Biscay & -0.53746 & 0.18999 & 0.120 \\
\hline & Other & -0.39130 & 0.33414 & 0.956 \\
\hline \multirow{7}{*}{ Burgos } & Gipuzkoa & -0.18039 & 0.39797 & 1.000 \\
\hline & La Rioja & 0.47778 & 0.26548 & 0.682 \\
\hline & Navarre & 0.46667 & 0.27027 & 0.725 \\
\hline & Palencia & 0.92121 & 0.29154 & 0.078 \\
\hline & Cantabria & 0.26667 & 0.33568 & 0.996 \\
\hline & Biscay & -0.17949 & 0.26912 & 0.999 \\
\hline & Other & -0.03333 & 0.38468 & 1.000 \\
\hline \multirow{6}{*}{ Gipuzkoa } & La Rioja & 0.65817 & 0.34222 & 0.607 \\
\hline & Navarre & 0.64706 & 0.34595 & 0.639 \\
\hline & Palencia & 1.10160 & 0.36281 & 0.105 \\
\hline & Cantabria & 0.44706 & 0.39914 & 0.967 \\
\hline & Biscay & 0.00090 & 0.34505 & 1.000 \\
\hline & Other & 0.14706 & 0.44115 & 1.000 \\
\hline \multirow{5}{*}{ La Rioja } & Navarre & -0.01111 & 0.17826 & 1.000 \\
\hline & Palencia & 0.44343 & 0.20911 & 0.473 \\
\hline & Cantabria & -0.21111 & 0.26723 & 0.997 \\
\hline & Biscay & $-0.65726^{* *}$ & 0.17652 & $0.008^{* *}$ \\
\hline & Other & -0.51111 & 0.32667 & 0.814 \\
\hline \multirow{4}{*}{ Navarre } & Palencia & 0.45455 & 0.21516 & 0.478 \\
\hline & Cantabria & -0.20000 & 0.27199 & 0.998 \\
\hline & Biscay & -0.64615 * & 0.18364 & 0.018 * \\
\hline & Other & -0.50000 & 0.33057 & 0.840 \\
\hline \multirow{3}{*}{ Palencia } & Cantabria & -0.65455 & 0.29314 & 0.400 \\
\hline & Biscay & $-1.10070^{* * *}$ & 0.21372 & $0.000^{* * *}$ \\
\hline & Other & -0.95455 & 0.34818 & 0.176 \\
\hline \multirow{2}{*}{ Cantabria } & Biscay & -0.44615 & 0.27085 & 0.775 \\
\hline & Other & -0.30000 & 0.38589 & 0.997 \\
\hline Biscay & Other & 0.14615 & 0.32963 & 1.000 \\
\hline
\end{tabular}

The schools were the preferred scenarios for leisure shared by grandparents and grandchildren in Cantabria $(\bar{X}=0.65)$ compared to Vizcaya $(\bar{X}=0.10)$. The rest of the provinces showed no significant differences in the practice of shared leisure in schools $\left(\overline{\mathrm{X}}_{\text {Burgos }}=0.00 ; \overline{\mathrm{X}}_{\text {Other }}=0.05 ; \overline{\mathrm{X}}_{\text {Palencia }}=0.90 ; \overline{\mathrm{X}}_{\text {Navarre }}=0.15 ; \overline{\mathrm{X}}_{\text {Gipuzkoa }}=0.17 ; \overline{\mathrm{X}}_{\text {Alava }}=0.21 ;\right.$ $\left.\overline{\mathrm{X}}_{\text {La Rioja }}=0.35\right)($ Table 6). 
Table 6. Multiple comparisons using the Games-Howell test: analysis of the use of schools for the practice of leisure shared by grandparents and grandchildren considering grandparents' province of residence.

\begin{tabular}{|c|c|c|c|c|}
\hline $\begin{array}{l}\text { (I) Grandparents' } \\
\text { Province of } \\
\text { Residence }\end{array}$ & $\begin{array}{l}\text { (J) Grandparents' } \\
\text { Province of } \\
\text { Residence }\end{array}$ & $\begin{array}{l}\text { Difference of } \\
\text { Means (I-J) }\end{array}$ & Standard Error & $p$ \\
\hline \multirow{8}{*}{ Alava } & Burgos & 0.21739 & 0.10268 & 0.475 \\
\hline & Gipuzkoa & 0.04092 & 0.14010 & 1.000 \\
\hline & La Rioja & -0.13816 & 0.12792 & 0.976 \\
\hline & Navarre & 0.06184 & 0.14353 & 1.000 \\
\hline & Palencia & 0.12648 & 0.12033 & 0.979 \\
\hline & Cantabria & -0.43975 & 0.25998 & 0.748 \\
\hline & Biscay & 0.10970 & 0.12414 & 0.993 \\
\hline & Other & 0.16739 & 0.11421 & 0.867 \\
\hline \multirow{7}{*}{ Burgos } & Gipuzkoa & -0.17647 & 0.09531 & 0.652 \\
\hline & La Rioja & -0.35556 & 0.20212 & 0.709 \\
\hline & Navarre & -0.15556 & 0.10028 & 0.825 \\
\hline & Palencia & -0.09091 & 0.06273 & 0.866 \\
\hline & Cantabria & -0.65714 & 0.23884 & 0.168 \\
\hline & Biscay & -0.10769 & 0.06976 & 0.830 \\
\hline & Other & -0.05000 & 0.05000 & 0.981 \\
\hline \multirow{6}{*}{ Gipuzkoa } & La Rioja & -0.17908 & 0.12208 & 0.864 \\
\hline & Navarre & 0.02092 & 0.13834 & 1.000 \\
\hline & Palencia & 0.08556 & 0.11410 & 0.997 \\
\hline & Cantabria & -0.48067 & 0.25716 & 0.637 \\
\hline & Biscay & 0.06878 & 0.11811 & 1.000 \\
\hline & Other & 0.12647 & 0.10762 & 0.954 \\
\hline \multirow{5}{*}{ La Rioja } & Navarre & 0.20000 & 0.12600 & 0.809 \\
\hline & Palencia & 0.26465 & 0.09877 & 0.171 \\
\hline & Cantabria & -0.30159 & 0.25073 & 0.951 \\
\hline & Biscay & 0.24786 & 0.10338 & 0.293 \\
\hline & Other & 0.30556 & 0.17916 & 0.743 \\
\hline \multirow{4}{*}{ Navarre } & Palencia & 0.06465 & 0.11829 & 1.000 \\
\hline & Cantabria & -0.50159 & 0.25904 & 0.593 \\
\hline & Biscay & 0.04786 & 0.12216 & 1.000 \\
\hline & Other & 0.10556 & 0.11205 & 0.989 \\
\hline \multirow{3}{*}{ Palencia } & Cantabria & -0.56623 & 0.24695 & 0.371 \\
\hline & Biscay & -0.01678 & 0.09382 & 1.000 \\
\hline & Other & 0.04091 & 0.08022 & 1.000 \\
\hline \multirow{2}{*}{ Cantabria } & Biscay & $0.54945^{*}$ & 0.15194 & 0.010 * \\
\hline & Other & 0.60714 & 0.20315 & 0.073 \\
\hline Biscay & Other & 0.05769 & 0.18532 & 1.000 \\
\hline
\end{tabular}

There were no significant differences by province in the use of municipal spaces (sports centers, cultural centers, playrooms, etc.), open public spaces, or the natural environment.

\section{Discussion}

This research revealed that the home of grandparents and/or grandchildren becomes the stage par excellence of the joint practice of cultural activities, in line with the findings obtained by the study of [39], which revealed the use of the home as a preferred space for intergenerational exchanges.

Among the most frequently performed and preferred shared leisure cultural activities at home were board games, watching television, and reading. This coincides with the results obtained in previous studies, which underlined that the most frequently shared practices were playing and watching television [9,13-15]. Childhood and old age are vital 
stages that share the common element of the need to play; culture is also very important in their relationships because grandparents are the main transmitters of values and cultural capital, ensuring that the grandchildren receive these values. The grandparents are responsible for transferring them to future generations. This ensures that play and culture are established as a link in intergenerational relations [40].

This work also showed that outdoor public spaces are less used by both generations, and thereby optimizing intergenerational communication. In these public spaces, intergenerational experiences focus primarily on going out to eat or drink, shopping, and physical activity [18]. Research shows that the promotion of these activities in public spaces has a positive impact on participation and the improvement of interpersonal relationships. Hence, they constitute ideal contexts for encounters, coexistence, and social interaction between different generations.

The natural environment was also identified as a space for facilitating intergenerational leisure activities, mainly to share trips and excursions. This finding corroborates the study of [37] and generates optimism, given the disturbing data that point to children's distance from this type of practice [41]. Different studies also reveal excursions and trips in the natural environment as leisure experiences less frequently shared by grandparents and grandchildren [13-15]. These data may be due to the turn of the decade, as currently, multigenerational trips are more frequent and are even becoming a global phenomenon. These activities should be a priority in the joint practice of grandparents and grandchildren, especially because of their potential to promote intergenerational learning, sensitivity, and environmental sustainability [32-36].

The present research discards the influence of living on the coast or inland in the use of the family home, as well as of public spaces and the natural environment as scenarios for intergenerational practice. Significant differences are found in the use of associations, municipal spaces (sports centers, cultural centers, playrooms, etc.), and educational centers for the leisure experience of grandparents and grandchildren, but they are more frequently used in inland populations, which would confirm our first hypothesis. This fact may be justified by the climate of the territories, as the areas of the inland peninsula have a greater thermal amplitude - colder winters and hotter summers-which invite the use of these contexts. In addition, the mountainous terrain of these areas conditions their climatic characteristics, producing a decrease in temperatures as the altitude increases.

It is interesting to highlight another finding that the present research discovered: Grandparents and grandchildren who live in urban populations and coastal municipalities have a greater preference for the use of private leisure spaces. This coincides with the assertions of [4], who argues that private spaces intended for leisure in cities such as shopping malls have become new emergent leisure spaces, especially for older people, who appropriate them as places of significant leisure for social encounters.

In addition, the results obtained corroborate our second hypothesis, showing that in rural areas, the use of private spaces for the practice of grandparents' and grandchildren's shared leisure is significantly less important than in urban areas. We verified that the grandparents' residence in the different geographical areas under study conditions the spaces of shared leisure practice.

Although some studies confirm that a rainy climate reduces the time spent on leisure activities [42], this research indicates that it can also be a factor with an impact on the space chosen for the practice of shared leisure by grandparents and grandchildren, confirming our third hypothesis that stated that the fact of residing in provinces with a rainier climate made the home of the grandparents and the grandchildren the preferred place in which to share leisure activities. On the one hand, grandparents who live in provinces characterized by this climatology, such as Cantabria and Gipuzkoa, relate more to their grandchildren at home than do grandparents in La Rioja and Palencia, colder areas, but also drier. In this same line, the Cantabrian grandparents use these scenarios more to relate to their grandchildren than the grandparents from Alava and Burgos, which are also colder and drier municipalities. 
Regarding open public spaces, it was found that grandparents living in Cantabria use them more to relate to their grandchildren than grandparents in Burgos, whereas the grandparents of Biscay use more private leisure spaces for joint practice than grandparents from Palencia, La Rioja, and Navarre. This may be due to the great effort developed in the last two decades in the capital of Biscay for the economic revitalization of Metropolitan Bilbao, with a strong commitment to materialize the potential of tertiary and leisure activities in the metropolitan and regional economy in the same locations in which industrialization was a leader in the past [43].

The schools are reference spaces for the joint practice of grandparents and grandchildren in the province of Cantabria compared to that of Biscay.

This article focuses on the types of spaces and the place of residence of the grandparents and grandchildren, although intergenerational relationships depend on a complex ecosystem of variables that cannot be considered in this case. However, they are contemplated in a broader research in which this publication is framed (age, gender, maternal or paternal grandparent, professional status, motivations that guide the practice, the predominant role of the grandparents with their grandchildren, etc.).

As a limitation of this study, social desirability may have determined the responses obtained, as previous works confirm people's predisposition to increase the levels of satisfaction of their responses when there are emotional and affective bonds [44].

This study highlights a reality before the COVID-19 pandemic. Given that there have been significant alterations in the relationship between grandparents and grandchildren [45-47], it is proposed as a prospective study to expand the research to understand the implications of the pandemic in intergenerational leisure.

\section{Conclusions}

The home of grandparents and/or grandchildren becomes the preferred space for cultural leisure activities; public spaces are the preferred contexts to go out for a snack, go shopping, practice physical activities, and go to the movies, whereas the natural environment is the preferred place for trips and excursions.

Whereas associations, municipal spaces, and schools are the more frequently chosen scenarios in inland municipalities for grandparents' and grandchildren's intergenerational relationships, private leisure spaces are used more frequently by the two generations living in coastal towns. In rural areas, private spaces are less important for shared leisure than in urban areas.

According to the different geographical areas under study, the place of residence conditions the spaces of grandparents' and grandchildren's shared leisure, so this factor should be considered in the creation, conservation, maintenance, and provision of leisure spaces that guarantee the access and quality of this practice.

Author Contributions: M.S.d.J.O., E.S.A., M.Á.V.S.E., R.A.A.R. and A.P.d.L.E. participated equally in the article, each contributing in equal measure to conceptualization, methodological design, analysis of results, and discussion. They have also all contributed equally to the writing of the initial draft, the continued supervision, and the final writing of the manuscript. All authors have read and agreed to the published version of the manuscript.

Funding: This research was co-financed under the National R\&D\&I Plan, grant number EDU201785642-R (years 2017-2020) from the Ministry of Economy and Competitiveness, and the European Regional Development Fund (ERDF), and it constitutes the initiation of the National R\&D\&I Plan, grant number PID2020-119438RB-I00 (years 2021-2024) from the Ministry of Science and Innovation.

Institutional Review Board Statement: The study was conducted according to the guidelines of the Declaration of Helsinki, and approved by the Ethics Committee of the University of La Rioja (Spain) on 17 December 2019 (code CE_02_2019).

Informed Consent Statement: Informed consent was obtained from all subjects involved in the study.

Data Availability Statement: This research was approved by the Ethics Committee of the University of La Rioja (Spain) on 17 December 2019 (code CE_02_2019). 
Conflicts of Interest: The authors declare no conflict of interest. The funders had no role in the design of the study; in the collection, analyses, or interpretation of data; in the writing of the manuscript, or in the decision to publish the results.

\section{References}

1. Monteagudo, M.J.; Lema, R. Iberoamérica en clave de ocio y recreación: Espacios para la construcción ciudadana. In Espacios de Ocio y Recreación para la Construcción de Ciudadaní; Monteagudo, M.J., Lema, R., Eds.; Documentos de Estudios de Ocio, 58: Bilbao, Spain, 2016; pp. 9-24.

2. Pinheiro de Almeida, M.T.; Gonçalves Siebra, L.M. El ocio infanto-juvenil en los espacios públicos de Barcelona. Psicol. Soc. 2015, 25, 173-199. [CrossRef]

3. González-García, J.M.; Bayón, F.; Meloni González, C. Repensar la Ciudad Desde el Ocio; Universidad de Deusto: Bilbao, Spain, 2015.

4. Cardona, B.M. Espacios de ciudad y estilos de vida. El espacio público y sus apropiaciones. Rev. Educ. Deporte 2008, $27,39-47$.

5. Burbano, A.M. El espacio público como un ensamblaje de lugares producidos por discursos y prácticas. Rev. Pretil 2013, 3, 7-12.

6. Kaztman, R. Seducidos y abandonados: El aislamiento social de los pobres urbanos. Rev. CEPAL 2001, 75, 171-189. [CrossRef]

7. González-Bencomo, H.; Calero, C.G.; Delgado, C.R. Espacio público y relaciones intergeneracionales: El caso de la Alameda en Santa Cruz de Tenerife (Canarias, España). In XXI Coloquio de Historia Canario-Americana; Cabildo Insular de Gran Canaria: Las Palmas, Spain, 2016; pp. 1-10.

8. Páramo, P. Aprendizaje Situado: Creación y Modificación de Prácticas Sociales en el Espacio Público Urbano. Psicol. Soc. 2010, 22, 130-138. [CrossRef]

9. Argento, N. El vínculo abuelos-nietos en una muestra de CABA y GBA. Intersecc. PSI. Rev. Electrónica Fac. Psicol. 2018, 26, 28-30.

10. Höpflinger, F. Introduction: Concepts, définitions et théories. In Générations-Structures et Relations, Rapport Générationsen Suisse; Perrig-Chiello, P., Höpflinger, F., Suter, C., Eds.; Seismo: Zurich,Switzerland; Geneva, Switzerland, 2009; pp. 18-41.

11. Pinazo, S.; Montoro, J. La relación entre abuelos y nietos: Factores que predicen la calidad de la relación intergeneracional. Rev. Int. Sociol. 2004, 38, 147-168. [CrossRef]

12. Sanz, E.; Valdemoros, M.A.; Ponce de León, A.; Alonso, R.A.; Sáenz de Jubera, M. Ocio y bienestar en clave intergeneracional. In Tiempos, Educación y Ocio en una Sociedad de Redes; Caride, J.A., Caballo, M.B., Gradaille, R., Eds.; Octaedro: Barcelona, Spain, 2020; pp. 139-152.

13. González Bernal, J.; de la Fuente, R. Relevancia psico-socio-educativa de las relaciones generacionales abuelo-nieto. Rev. Española Pedagog. 2008, 239, 103-118.

14. González Bernal, J.J.; González Santos, J.; González Bernal, N.; Marquínez, S. Análisis de las actividades que realiza el abuelo o la abuela con nieto-nieta según el sexo y la edad del nieto o nieta. INFAD Rev. Psicol. 2009, 1, 443-452.

15. Tyszkowa, M. The role of grandparents in the development of grandchildren as perceived by adolescents and young adults in Poland. In The Psychology of Grandparenthood: An International Perspective; Smith, K., Ed.; Routledge: London, UK, 2005; pp. 59-65.

16. Gram, M.; O’Donohoe, S.; Schänzel, H.; Marchant, C.; Kastarinen, A. Fun time, finite time: Temporal and emotional dimensions of grandtravel experiences. Ann. Tour. Res. 2020, 85, 102949. [CrossRef]

17. Rodríguez, H.; Sandoval, L. Calidad de Vida. Los Espacios de Recreación. Hacia una Planeación Integral. Delegación Azcapotzalco; UAMA: Ciudad de México, Mexico, 2010.

18. Ortiz, O.R.; González, V.; Carrillo, V.; Loreto, N. Reducción de la inseguridad en Ciudad Juárez mediante la recuperación de espacios públicos. Cultura Científica Tecnológica 2013, 49, 15-25.

19. Molina, V.A.; Tabares, J.F. Ocio y Ciudad: Diálogos para la Construcción de Espacios Lúdicos; Corporación Cívitas: Santiago de Cali, Colombia, 2007.

20. Rivera, L.M. Los parques urbanos como indicadores de calidad de vida, símbolos de bienestar y espacios de uso recreativo: Una investigación en Bucaramanga (Colombia). Univ. Empresa 2014, 16, 207-229. [CrossRef]

21. World Cities Report 2020. The Value of Sustainable Urbanization. UN-Habitat. Available online: https://unhabitat.org/wcr/ (accessed on 15 May 2021).

22. Thianthai, C. Health Connections in Intergenerational Relationships: A Case Study on the Impact of Familial Activities on the Health and Well-being of Young and Elderly People in Bangkok, Thailand. J. Intergener. Relatsh. 2019, 18, 156-174. [CrossRef]

23. Delgado, C.R.; Calero, C.G. Espacios de convivencia y experiencia intergeneracional. Trab. Soc. Hoy 2017, 82, 19-40. [CrossRef]

24. Sánchez-Oro, M.; Pérez, J.A.; Moreno, J. Los mayores en el continuo rural-urbano. Aproximación a la percepción subjetiva y expectativas vitales (el caso de Extremadura). Pap. Rev. Sociol. 2013, 98, 143-174. [CrossRef]

25. $\mathrm{Xu}, \mathrm{H}$. Physical and mental health of Chinese grandparents caring for grandchildren and great-grandparents. Soc. Sci. Med. 2019, 229, 106-116. [CrossRef] [PubMed]

26. Beaumont, E.; Sterry, P. A study of grandparents and grandchildren as visitors to museums and art galleries in the UK. Mus. Soc. 2005, 3, 167-180.

27. Melgar, M.F.; Tuninetti, V. Museos y Vinculación intergeneracional. Estudios de valoraciones de una propuesta educativa. Rev. Mus. Antropol. 2017, 10, 87-96. [CrossRef]

28. Sanford, C.; Knutson, K.; Crowley, K. “We Always Spend Time Together on Sundays": How Grandparents and Their Grandchildren Think About and Use Informal Learning Spaces. Visit. Stud. 2007, 10, 136-151. [CrossRef] 
29. Becerril, R.; Bores, N. Claves para el diseño de propuestas educativas intergeneracionales a partir de una experiencia de actividad física. Ágora Educ. Física Deporte 2019, 21, 111-124. [CrossRef]

30. Castell, C. Naturaleza y salud: Una alianza necesaria. Gac. Sanit. 2020, 34, 194-196. [CrossRef] [PubMed]

31. Yoo, J.; Russell, D.W. Caring for Grandchildren and Grandparents' Physical and Mental Health Changes. J. Child Fam. Stud. 2020, 29, 845-854. [CrossRef]

32. Esteban, M.; Amador, L. El huerto social como estrategia para la educación ambiental. Agric. Soc. Desarro. 2020, 17, 321-347. [CrossRef]

33. García, J.C.; Gutiérrez, J.G.; Balderas, M.A.; Araújo, M.R. Beneficios socioculturales y ambientales de los huertos familiares en el altiplano mexicano. Bois Forêts Trop. 2017, 329, 29-42. [CrossRef]

34. Hake, B.J. Gardens as Learning Spaces: Intergenerational Learning in Urban Food Gardens. J. Intergener. Relatsh. 2017, 15, 26-38. [CrossRef]

35. Jamieson, L. Families, relationships and 'environment': (Un)sustainability, climate change and biodiversity loss. Fam. Relatsh. Soc. 2016, 5, 335-355. [CrossRef]

36. Kala, L.; Galčanová, L. Intergenerational Transmission of Pro-Environmental Values and Lifestyles: How Is the Ecological Habitus Reproduced? In Third ISA Forum-The Futures We Want: Global Sociology and the Struggles for a Better World; Sage: Vienna, Austria, 2016.

37. Ponce de León, A.; Valdemoros, M.A.; Sanz, E.; Sáenz de Jubera, M.; Alonso, R.A. Ocio ambiental-ecológico compartido entre abuelos/as y nietos/as. Terra. Rev. Desarolo Local 2021, 232-252. [CrossRef]

38. Neustaedter, C.; Heshmat, Y.; Jones, B.; Forghani, A.; Xiong, X. Shared Family Experiences Over Distance in the Outdoors. In HCI Outdoors: Theory, Design, Methods and Applications. Human-Computer Interaction Series; McCrickard, D.S., Jones, M., Stelter, T.L., Eds.; Springer: New York, NY, USA, 2020; pp. 155-174. [CrossRef]

39. Jessel, J.; Kenner, C.; Gregory, E.; Ruby, M.; Arju, T. Different spaces: Learning and literacy with children and their grandparents in east London homes. Linguist. Educ. 2011, 22, 37-50. [CrossRef]

40. Valdemoros, M.A.; Sáenz de Jubera, M.; Medrano, C.; Santamaría, M. Fusión de cultura y juego en escenarios de ocio intergeneracional. In Estudios Sobre Innovaciones Educativas; Felipe, A., Peña, B., Bobkina, J., Eds.; Pirámide: Madrid, Spain, 2019; pp. 443-456.

41. Edwards, R.C.; Brendon, M.H.; Larson, B.M.H. When screens replace backyards: Strategies to connect digital-media-oriented young people to nature. Environ. Educ. Res. 2020, 26, 950-968. [CrossRef]

42. Connolly, M. Here comes the rain again: Weather and the intertemporal substitution of leisure. J. Labor Econ. 2008, 26, 73-100. [CrossRef]

43. Ortega, C.; Bayón, F. Cultural Mapping and Urban Regeneration: Analyzing Emergent Narratives about Bilbao. Cult. Local Gov. 2015, 5, 9-22. [CrossRef]

44. Caputo, A. La deseabilidad social parece mejorar las medidas de bienestar, pues los individuos tienden a aumentar el grado de satisfacción y felicidad que resulta en artefactos de respuesta y en una seria amenaza para la validez de los datos por autoinforme. Univ. Psychol. 2014, 16, 93-102.

45. Brooks, S.K.; Webster, R.K.; Smith, L.E.; Woodland, L.; Wessely, S.; Greenberg, N.; Rubin, G.J. The psychological impact of quarantine and how to reduce it: Rapid review of the evidence. Lancet 2020, 395, 912-920. [CrossRef]

46. Dalton, L.; Rapa, E.; Stein, A. Protecting the psychological health of children through effective communication about COVIDLancet Child Adolesc. Health 2020, 4, 346-347. [CrossRef]

47. Wang, G.; Zhang, Y.; Zhao, J.; Zhang, J.; Jiang, F. Mitigate the effects of home confinement on children during the COVID-19 outbreak. Lancet 2020, 395, 945-947. [CrossRef] 